\title{
The role of autophagy in hepatocellular carcinoma: friend or foe
}

\author{
Lian Liu' ${ }^{1}$ Jia-Zhi Liao ${ }^{1}$, Xing-Xing He ${ }^{1}$ and Pei-Yuan Li ${ }^{1}$ \\ ${ }^{1}$ Institute of Liver Diseases, Tongji Hospital, Tongji Medical College, Huazhong University of Science and Technology, Wuhan, \\ China \\ Correspondence to: Pei-Yuan Li, email: pyli@tjh.tjmu.edu.cn \\ Xing-Xing He, email: xxhe@tjh.tjmu.edu.cn \\ Keywords: autophagy, hepatocellular carcinoma, signaling pathways, biomarkers, tumor therapy
}

Received: January 09, 2017

Accepted: April 06, 2017

Published: April 18, 2017

Copyright: Liu et al. This is an open-access article distributed under the terms of the Creative Commons Attribution License 3.0 (CC BY 3.0 ), which permits unrestricted use, distribution, and reproduction in any medium, provided the original author and source are credited.

\section{ABSTRACT}

Autophagy is an evolutionarily conserved lysosome-dependent catabolic process which degrades cell's components in order to recycle substrates to exert optimally and adapt to tough circumstances. It is a critical cellular homeostatic mechanism with stress resistance, immunity, antiaging, and pro-tumor or anti-tumor effects. Among these, the role of autophagy in cancer is the most eye-catching that is not immutable but dynamic and highly complex. Basal autophagy acts as a tumor suppressor by maintaining genomic stability in normal cells. However, once a tumor is established, unbalanced autophagy will contribute to carcinoma cell survival under tumor microenvironment and in turn promote tumor growth and development. The dynamic role of autophagy can also apply on hepatocellular carcinoma (HCC). HCC is a highly malignant cancer with high morbidity and poor survival rate. Decline or overexpression of autophagic essential genes such as ATG7, ATG5 or Beclin 1 plays a key role in the occurrence and development of HCC but the exact mechanisms are still highly controversial. Signaling pathways or molecules involving in autophagy, for example PI3K/AKT/mTOR pathway, ERK/MAPK pathway, PERK pathway, p53, LncRNA PTENP1 (Long non-coding RNA PTENP1), microRNA-375 and so on, occupy an important position in the complex role of autophagy in HCC. Here, we discuss the dynamic role, the signaling pathways and the potential prognostic and therapy value of autophagy in HCC.

\section{INTRODUCTION}

Since Christian de Duve proposed the term 'autophagy', which he introduced at the CIBA Foundation Symposium on Lysosomes in 1963 [1], growing enthusiasm has done much to the discovery of characteristics and functions of autophagy. Excitedly, last year's Nobel Prize in Physiology or Medicine was about the great discovery of autophagy. This inspiring news encouraged researchers to explore more fundamental questions about autophagy. According to the different delivery modes of cargos to lysosome or vacuole, there are three primary forms of autophagy: chaperone-mediated autophagy, microautophagy and macroautophagy [2]. Among them, macroautophagy (hereafter referred to as autophagy) is the most studied, which occurs constitutively at a low level and can be further induced under stress conditions [3, 4]. More importantly, dysfunction of autophagy contributes to the pathologies of many human diseases, for instance, neurodegenerative diseases [5], fatty liver disease [6], lupus disease [7], Crohn's disease [8], and cancers including HCC (hepatocellular carcinoma) [9].

HCC, a highly malignant cancer with a high recurrence rate and a poor prognosis, is the third leading cause of cancer death worldwide and the second leading cause of cancer death among men in less developed countries $[10,11]$. Although surgical resection or transplantation helps to improve survival rates of patients, there is still no effective treatment for the advanced patients who are not eligible for surgery. It results in only a median OS (overall survival) of 6.6 months for these patients $[12,13]$. Therefore, it is imperative to explore effective and safe prognostic biomarkers and therapeutic targets for the advanced HCC patients.

Autophagy probably involves in both the promotion and prevention of cancer, and its roles may be changed during tumor progression $[14,15]$. It helps to carcinoma cell survival under tumor microenvironment including 
chemotherapies while suppresses tumor initiation in normal liver by ensuring the normal function of cells [16]. Unfortunately, the exact mechanisms are not fully understood until now. Since the dynamic and fundamental role of autophagy in HCC, this review focuses on elucidating cellular and molecular characteristics of autophagy, dynamic role and pathways of autophagy in $\mathrm{HCC}$, and autophagy-related potential prognostic biomarkers and therapeutic targets for HCC.

\section{Characteristics and physiological roles of autophagy}

\section{The characteristics of autophagy}

The discovery of autophagy essential gene ATG1 has led to a recent upsurge in autophagy exploration [17], which followed by identification of dozens of related genes. Up to date, multiple laboratories have found almost $40 A T G$ genes in yeast, many of which have orthologs in higher eukaryotes [18]. The ATG protein products of $A T G$ genes (hereafter, italic for the gene, non-italic for the protein) involving in autophagosome formation consist of four function units and some additional factors in mammalian: (a) ULK1 complex; (b) PI3KC III (Class III phosphatidylinositol 3-kinase complex); (c) ATG12 conjugation system; (d) LC3 (microtubule-associated protein light chain 3) conjugation system; and additional factors WIPI-2, ATG2, and ATG9. Functions and components of these units are summarized in Table 1.

Once mTORC1 (mammalian target of rapamycin complex 1) is blocked in amino acid-deficient conditions, the most upstream unit ULK1 complex is activated, followed by nucleation and expand of phagophore (an expanding membrane sac) (See Figure 1A and 1E). The ULK1 complex is assembled by ULK1 (mammalian homolog of yeast Atg1), ATG13, FIP200 (focal adhesion kinase family interacting protein of $200 \mathrm{kD}$, also known as retinoblastoma 1-inducible coiled-coil 1, RB1CC1), and ATG101 (See Figure 1A). It initiates the formation of autophagosome and links cellular nutrient status to downstream events in autophagy [19-26]. Activated ULK1 complex leads to recruiting of PI3KC III to phagophore [27]. Autophagy-specific PI3KC III, downstream of ULK1 complex, consists of Beclin 1 (a mammalian homolog of yeast Atg6), ATG14, Vps34, and $h V p s 15$, recruiting the subsequent ATG proteins onto phagophore membrane (See Figure 1B) [28-30]. The following units are the two ubiquitylation-like modification systems-ATG12 conjugation system and the LC3 conjugation system which contribute to the elongation of the phagophore (See Figure 1C, 1D) [31-34]. In addition, proteins WIPI-2, ATG2, and ATG9 also play irreplaceably role in the membrane recruitment and the formation of autophagosome, which are described in Table 1 [29, 35-37]. These autophagic factors gather tightly at ER (endoplasmic reticulum) associated structures called omegasomes [26, 38]. The phagophore then fully surrounds its cargos including unfolded proteins, cytoplasm, superfluous or damaged organelles and fuses to form the closed autophagosome [18, 39]. Subsequently, autophagosome merges with the lysosome in mammalian cells to form an autolysosome [18]. Eventually, the inner membrane and the enclosed cargos are degraded by protease or nuclease (See Figure 1E) [39]. By this way, the degradation products of cytoplasm portions will be cycled for energy generating and substrate supplying [40]. Thus, this process can be referred as a material recycling system and energy efficient utilization mechanism under nutritional starvation or other tough conditions such as tumor microenvironment.

Regulation of ATG proteins activity plays a critical role in the balance of autophagy in mammalian cells. Increasing evidence indicates that PTMs (posttranslational modifications) of ATG proteins have significant flexibility for the balance of autophagy [41, 42]. Different PTMs play critical role in the promotion or inhibition of ATG proteins in different stages of autophagy and can trigger distinct responses in autophagy [43]. Besides, ATG proteins can be modified multiple times by different PTMs or the same PTM at different residues [43]. For example, ULK1 maintains its kinase activity through autophosphorylation at Thr180 [44], promotes its self-association and activity during autophagy by ubiquitination [45], stimulates starvation-induced autophagy by acetylation at Lys 162 [46]. These complex and precise PTMs regulate activity of ATG proteins during autophagic process which will provide new therapeutic targets for the treatment of autophagy-associated diseases [43].

Collectively, autophagy is a very complex process that consists of ATG proteins and other components to assemble the required machinery [26].

\section{Physiological functions of autophagy}

Researches on autophagy and tumor suppressing began to spring up since the relationship between autophagy and malignant transformation has been established. Decrease in autophagic capacity was observed in numerous cancers $[47,48]$. For instance, lower autophagic capacity is detected in chemical carcinogens induced preneoplastic liver nodules cells and primary rat HCC cells when compared with normal cells [49, 50]. Beclin 1 (mammalian homolog of yeast $A \operatorname{tg} 6$ ), an essential autophagy gene, has been found mono-allelically deleted in various cancers including liver, ovarian, breast, prostate, glioma, colon, and brain [51-57]. Besides, Beclin 1 is not the only one gene which binds autophagy and tumor, several oncogenes or tumor suppressor genes affect autophagyrelated pathways, the PTEN tumor suppressor genes and the Akt, Ras or Myc oncogenes, for example [58-63]. Accordingly, it is not difficult to conclude that there are numerous undiscovered genes or mechanisms exerting tumor suppressing role by contacting with autophagy. 
Table 1: Essential ATG proteins involved in autophagosome formation in mammalian

\begin{tabular}{|c|c|c|}
\hline Function units & Known or possible role & References \\
\hline \multicolumn{3}{|l|}{ ULK1 complex } \\
\hline ULK1 & Binds with ATG13, ATG101, and FIP200 & {$[19,20,163]$} \\
\hline ATG13 & $\begin{array}{l}\text { Bridges the interaction of ULK1 and FIP200; is required for the localization and } \\
\text { stability of ULK1 and stimulates the kinase activity of ULK1 }\end{array}$ & [164] \\
\hline ATG101 & $\begin{array}{l}\text { Interacts with ULK1 in an ATG13-dependent manner; regulates the stability and } \\
\text { basal phosphorylation of ATG13 and ULK1 }\end{array}$ & {$[24,25,164]$} \\
\hline FIP200 & $\begin{array}{l}\text { Scaffold protein, binds with ULK1 and ATG13; is required for proper } \\
\text { localization, stability and kinase activity of ULK1 }\end{array}$ & {$[19,20,29,164,165]$} \\
\hline \multicolumn{3}{|c|}{ PI3K complex III } \\
\hline Beclin 1 & $\mathrm{BH} 3$-only protein; interacts with $\mathrm{Bcl}-2$ & {$[28,29,39]$} \\
\hline ATG14L & Enhances Vps34 lipid kinase activity, upregulates autophagy & {$[28,30]$} \\
\hline hVps15 & $\mathrm{Ser} / \mathrm{Thr}$ protein kinase, is required for $\mathrm{Vps} 34$ membrane association & [166] \\
\hline Vps34 & PI3K, forms Phosphatidylinositol 3-phosphate (PI3P) for autophagy & {$[167,168]$} \\
\hline \multicolumn{3}{|c|}{ ATG12 conjugation system } \\
\hline ATG5 & Forms isopeptide bond with ATG12 & {$[31,169]$} \\
\hline ATG12 & Ubiquitin-like protein; forms isopeptide bond with Atg5 conjugation & {$[31,169]$} \\
\hline ATG7 & E1-like activating enzyme, catalyzes ATG12-ATG5 and LC3-II-PE conjugation & [31] \\
\hline ATG10 & E2-like activating enzyme; catalyzes ATG12-ATG5 & [31] \\
\hline ATG16L1 & Conjugates to ATG12-ATG5 complex & [170] \\
\hline \multicolumn{3}{|c|}{ LC3 conjugation system } \\
\hline LC3 & Ubiquitin-like protein, conjugates to $\mathrm{PE}$, an important marker of autophagy & {$[34,171]$} \\
\hline ATG4 & Cysteine protease, regulates the level of free LC3-I & {$[31,34]$} \\
\hline ATG7 & E1-like activating enzyme, catalyzes ATG12-ATG5 and LC3-II-PE conjugation & {$[31,34]$} \\
\hline ATG3 & E2-like conjugating enzyme analog, catalyzes LC3-II-PE conjugation & {$[31,34]$} \\
\hline \multicolumn{3}{|c|}{ Other essential proteins } \\
\hline WIPI-2 & $\begin{array}{l}\text { Mammalian homolog of yeast Atg18, a PI3P-binding protein, facilitates LC3 } \\
\text { lipidation }\end{array}$ & {$[35,172]$} \\
\hline ATG2 & Probably plays an essential role at late step of autophagosome formation & {$[29,36]$} \\
\hline ATG9 & $\begin{array}{l}\text { The only known transmembrane protein, may contribute to membrane } \\
\text { recruitment }\end{array}$ & [37] \\
\hline
\end{tabular}

Autophagic cell death, type-II programmed cell death, is a form of non-apoptotic cell death mechanism in which autophagy is a part of the events leading to cell death $[64,65]$. Yu et al. had reported that $A T G 7$ and Beclin 1, two essential autophagy genes, were necessary for apoptotic independent cell death in mammalian cells. Furthermore, ATG5 and Beclin 1 could also mediate death of MEFs (murine embryonic fibroblasts) whose apoptotic cell death had been blocked $[65,66]$. Both of the studies indirectly revealed that autophagy played an important role in cell death when apoptotic death was blocked.

Autophagy plays an essential role in intracellular quality controlling through the turnover of cytoplasmic components [67]. It has been reported that abnormal ubiquitinated proteins and organelles rapidly accumulated in the cytoplasm in autophagy genes ATG5 and ATG7 deficient liver tissue. And liver-specific $A T G 7^{-/-}$mice can develop hepatomegaly and hepatic failure which indicates the remarkable position of autophagy in liver metabolism [68]. Once basal autophagy dysregulated, not only liver, but also nervous system, cardiovascular system and many other tissues can be dysfunctional $[67,69,70]$. More importantly, increasing level of autophagy accelerates the turnover of amino acid in starvation conditions. For instance, autophagy is responsible for degradation of over $30 \%$ of total proteins in liver within one day in innutritious mice [68]. And autophagy derived amino acids can also be utilized for energy providing by the TCA (tricarboxylic acid) cycle which contributes to survival of cells [71]. Briefly, autophagy keeps cellular homeostasis by intracellular quality controlling and then promotes the survival of cells. 
In addition to the above functions, autophagy also plays a key role in determining life span [72]. The antiaging effect of autophagy is not only reflected in mammals but also in other organisms, such as yeast, $C$. elegans, and Drosophila [72, 73]. Autophagy is downregulated at the transcriptional level during normal human brain aging [74]. And dropping of BEC-1 (a Beclin 1 ortholog) could weaken the significantly extended life span of $C$. elegans [75]. In addition, CR (caloric restriction), the major antiaging measure, is the optimal

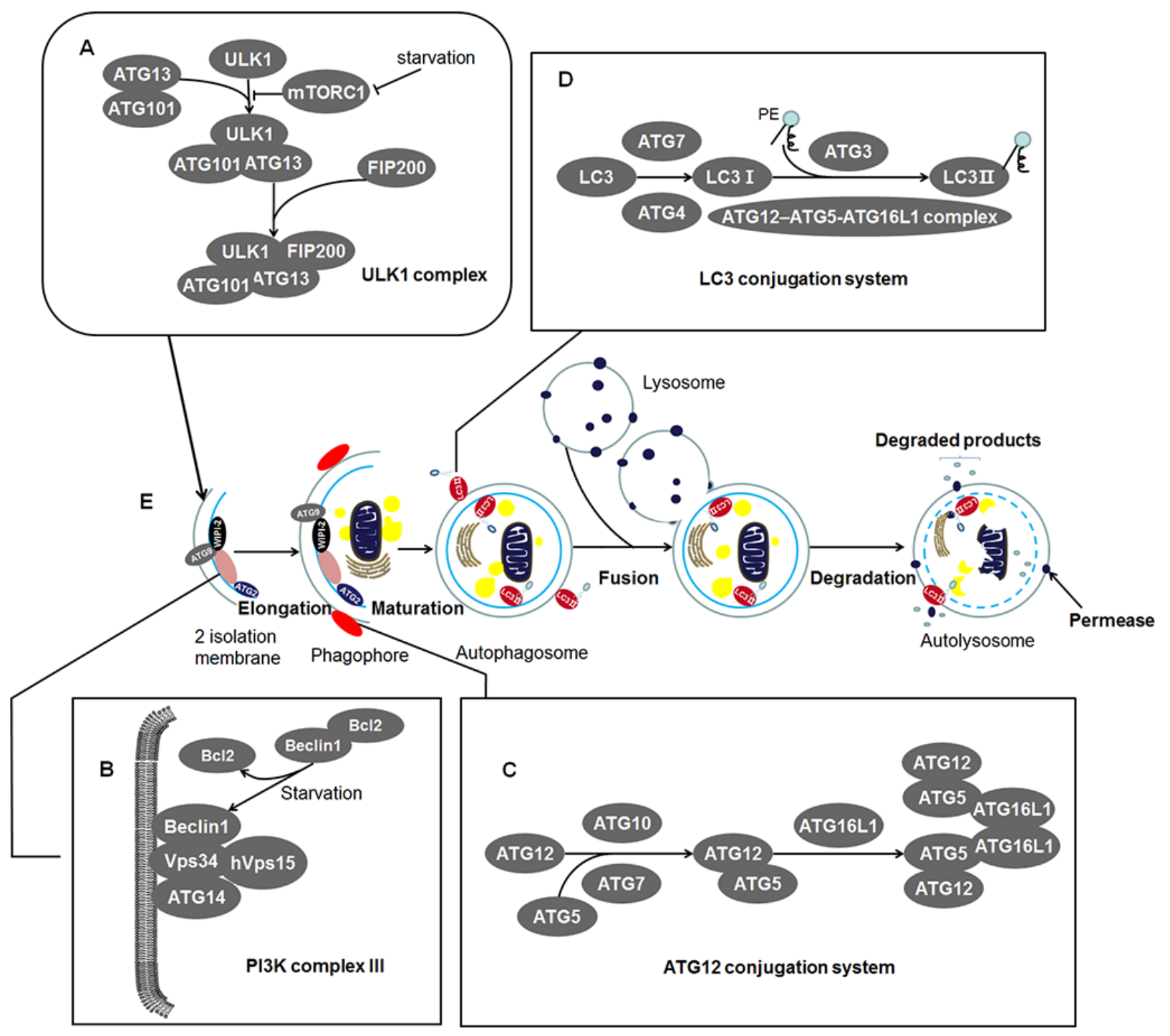

Figure 1: The characteristics of autophagy in mammals: Contents in the enlargement frames represent composition of the bilayer membrane. (A) ULK1 complex: An initiator of autophagy which locates at the phagophore. Under starvation condition, the mTORC1 is blocked and the activated ULK1 and ATG13 induce the initiation of autophagy. ATG101 participates in the process in an ATG13-dependent manner and FIP200 is another critical protein for the induction of autophagy. (B) PI3K complex III: Recruiting the subsequent ATG proteins onto phagophore membrane. It can be negatively regulated by binding of Bcl2 and Beclin 1 while Bcl2 will release Beclin 1 during starvation. This structure locates at inner membrane of the phagophore. (C) ATG12 conjugation system: ATG12 is irreversibly conjugated to ATG5 in an ATG7- and ATG10-dependent manner. The ATG12-ATG5 complex binds to ATG16L1 and then forms multimerization at the phagophore. (D) LC3 conjugation system: LC3 is processed by ATG4 and ATG7 to generate activated LC3-I. The ATG12-ATG5-ATG16L1 complex and ATG3 involve in the conjugation of phosphatidylethanolamine (PE) to LC3-I to create LC3-II. And then LC3-II inserts into the extending phagophore membrane. LC3-II locates at two sides of the phagophore until the formation of autophagosome, which is cleaved from the outer membrane of this structure. (E) Morphological characteristics of autophagy: During starvation, the ULK1 complex initiates the generation of the 2 isolation membrane which extends to form phagophore. The phagophore then fully surrounds its cargos including unfolded proteins, cytoplasm, superfluous or damaged organelles. These cargos are sequestered by phagophore and fuse to form the closed autophagosome. Among the essential proteins, WIPI-2, ATG9, and ATG2 proteins locate at phagophore and exert their unsubstituted role in the formation of autophagosome. Subsequently, autophagosome merges with lysosome in mammalian cells to form an autolysosome. Eventually, the inner membrane and the enclosed cargos is degraded by protease or nuclease. 
physiological inducer of autophagy [76, 77]. Inhibition of autophagy will weaken the antiaging effects of CR in multiple species, such as C. elegans [78], D. melanogaster [79], Drosophila [80], and mice [72, 81]. Of course, there are lots of other mechanisms involving in aging regulation. Autophagy is not necessary but, at least in some ways, also significant for life extension. Considering these reasons, it is possible that the promotion of autophagy may reduce the occurrence of time-dependent diseases and may provide a perfect introduction for aging research.

\section{Roles of autophagy in hepatocellular carcinoma (HCC)}

The characteristics of autophagy have been extensively investigated for more than 40 years, however, the actual functions of it in HCC are still not well known. Generally, the role of autophagy in liver cancer is not unchangeable but dynamic and easily affected [82]. During dysplastic phase in hepatocytes, basal autophagy acts as a tumor suppressor by removing newly damaged mitochondria and mutated cells and thus maintaining genomic stability. However, once a tumor is established, unbalanced autophagy will contribute to HCC cell survival under various stress conditions and in turn promotes tumor growth [83]. And autophagy inhibitors exerted a tumorsuppressive effects in the HCC rat model in tumor-forming stage while had a tumor-promoting effect in dysplastic stage [83]. Hence, the role of autophagy in the occurrence and development of HCC is dependent on the context of liver cells.

\section{Anti-tumor role of autophagy in liver cancer}

The key $A T G$ genes play critical role in the activation and the occurrence of autophagy. For example, the deletion of Beclin 1, ATG5, or ATG7 were found to associate with the tumor phenotype of HCC. In animal models the Beclin $1^{+-}$mutant mice developed increased frequency of spontaneous malignancies including $\mathrm{HCC}$ $[84,85]$. Meanwhile, expression levels of Beclin 1 were negatively related with $\mathrm{HCC}$ grades which in some case confirmed the positively significance of Beclin 1 to suggest the grades of HCC [86]. In addition, $\operatorname{Atg} 5^{f f o x} f f o x$ CAG-Cre mice, generated by crossing Atg $5^{\text {fox } f f o x}$ mice with CAG-Cre transgenic mice (CAG-Cre transgenic mice expressing Cre recombinase under the control of the CMV enhancer and chicken $\beta$-actin promoter), was incompletely deleted and prevented the lethal phenotype of $\operatorname{Atg} 5^{-1-}$. This kind of mice developed Atg5-deficient hepatocytes derived tumors only in liver which revealed the hepatic specific antitumor effect of autophagy [87]. Mice with liverspecific knockout of $\operatorname{Atg} 7$ also developed liver tumors in some degree [87]. The results of loss of key autophagic genes suggest that basal autophagy occupies an important position in preventing the occurrence and development of liver tumors.
Furthermore, p62 (a substrate of autophagy) accumulation induced by loss of autophagy contributes to hepatic tumor formation. It has been reported that tumors in p62 transgenic animals showed more active irregular mitosis and higher expression levels of IGF2 (Insulin-like Growth Factor II). However, Atg7-deficient mice with p62-deficient hepatocytes showed decreasing in tumor size. Besides, conclusion from a HBV-positive HCC cohort was consistent with the above results $[87,88]$. These appear that autophagy deficiency causes accumulation of p62 resulting in development of HCC. Indeed, autophagy deficiency increases the accumulation of damaged mitochondria, causes oxidative stress, and suppresses synthetic lethal deficiency in DNA repair which lead to chronic tissue damage and genome mutations in HPCs (hepatic progenitor cells) [89, 90]. The chronic damage and genome mutations of liver cells are the key factors of oncogenesis.

LncRNA PTENP1 (Long non-coding RNA PTENP1), a pseudogene of the tumor suppressor gene PTEN, induces autophagy as a pro-death response to suppress hepatocellular carcinoma [91, 92]. LncRNA PTENP1 acts as a competitive endogenous RNA and captures the miR-17, miR-19b, and miR-20a that target PTEN which inhibits the activation of PI3K/AKT signaling, thus preventing PTEN from being silenced. Therefore overexpression of LncRNA PTENP1 indirectly inhibited the PI3K/AKT pathway through PTEN overexpression and then induced pro-death autophagy resulting in death of HCC cells $[92,93]$. It means that LncRNA PTENP1 induced autophagy may act as an inhibitory factor for HCC cells survival.

In addition, we investigated the role of IFN- $\gamma$ which has a growth inhibitory effect on HCC and found that autophagy contributed to IFN- $\gamma$ induced proliferation inhibition as well as cell death in HCC cells. In our study, IFN- $\gamma$ inhibited the cell growth of Huh7 HCC cells with non-apoptotic cell death which was proved to be autophagy later. Subsequently, we confirmed that IFN- $\gamma$ stimulated autophagosome formation and encouraged autophagic signals changes and autophagic flux in HCC cells. Last but not least, blocking of autophagy abolished the proliferation inhibition and cell death effects of IFN- $\gamma$ on HCC. The results suggested that autophagy was essential for the proliferation inhibition effects of IFN- $\gamma$ on HCC cells [94].

All these lines of evidence elucidate that autophagy mediates anti-tumor effects and participates in various signaling pathways directly or indirectly to prevent the occurrence and progression of hepatocarcinoma.

\section{Pro-tumor role of autophagy in liver cancer}

However, the intracellular quality control and the amino acid cycle functions of autophagy may become an accomplice of cancer cell survival in starvation, hypoxia, 
metabolic stress and other stress conditions [16]. In other words, cells can survive this self-digestion to get an alternative energy source under tumor microenvironment. A $156 \mathrm{HCC}$ patients study reported that the expression levels of LC3-II (a key autophagic marker) in HCC were associated with vascular invasion $(P=0.016)$, lymph node metastasis $(P=0.042)$, and TNM stage $(P=0.037)$. Moreover, the overexpression of LC3-II predicted an inferior 5-year OS (overall survival) rate $(P=0.026)$, which suggested that the expression levels of autophagy were positively related with the development and a poor prognosis of HCC [95]. Indeed, increased autophagy has been detected in advanced liver cancer, and is closely related to malignant transformation and low survival rate in HCC patients [95-97].

Our team investigated the role of miR-375 which is one of the most significantly downregulated miRNAs in HCC and found that it inhibited autophagy by reducing the expression of $A \operatorname{tg} 7$ and then decreased viability of HCC cells under hypoxic conditions in culture and in mice. MiR-375 suppressed the conversion of LC3-I to LC3-II under hypoxic conditions which thereby blocked autophagic flux, inhibited mitochondrial autophagy of HCC cells, reduced the elimination of damaged mitochondria, increased releasing of mitochondrial apoptotic proteins, and then impaired viability of HCC cells $[98,99]$. The results indicate that autophagy promotes the survival of HCC cells under hypoxia in established HCC cells.

Autophagy encourages the development of liver cancer via inhibiting the expression of tumor suppressors or contributing to the chemoresistance of HCC cells. It had been argued that the above liver-specific Atg5 deficient mice developed only hepatic adenoma but not hepatic cancer was induced by the expression of tumor suppressors such as p53. Besides, Tian et al. found that impaired autophagy suppressed the development of HCC through inducing of tumor suppressors such as p53, p16, p21, and p 27 [100]. That is to say, HCC induced autophagy may block the anti-tumor effects of various tumor suppressors and blocking of autophagy may be an ideal target for the therapy of established HCC. Moreover, autophagy contributes to the chemoresistance of HCC cells. It has been reported that hypoxia induced autophagy decreased apoptotic potential of hepatocarcinoma cells resulting in chemoresistance. And inhibition of autophagy made HCC cells sensitive to chemotherapeutic agents. Sorafenib, the only FDA (Food and Drug Administration) approved HCC systemic therapy for instance, can stimulate the expression of multiple autophagy markers in HCC cells in vitro $[101,102]$. Some works have established that sorafenib induced autophagy acts as a chemoresistance mechanism in HCC. When the autophagic key genes Beclin 1 or Atg5 have been suppressed, sorafenib will kill more cancerous cells and its antiproliferative ability improves. These suggest that autophagy inhibitors may play a synergistic anti-tumor effect with chemotherapy [101]. In addition, autophagy also assists activated Ras proteins to maintain tumorigenesis [103-105]. In short, autophagy plays its full part through many direct or indirect ways ultimately to promote the growth of HCC cells.

Taken together, all these lines of evidence suggest that autophagy can act as an accomplice of survival, malignant progression and distant metastasis of hepatocellular carcinoma cells in tumor-forming stage. The pro-tumor role of autophagy in hepatocarcinoma is dependent on the stages of tumor development. And the inhibition of autophagy may be an effective anti-tumor mechanism in established liver cancer cells.

\section{Signaling pathways of autophagy in HCC}

\section{PI3K/AKT/mTOR pathway}

$\mathrm{PI} 3 \mathrm{~K} / \mathrm{AKT} / \mathrm{mTOR}$ pathway is a well-known signaling pathway which regulates cell growth, survival, metabolism and apoptosis in physiological conditions and takes great importance for the development and survival of multiple solid tumors including HCC [106-112]. AKT, the key factor of the signaling pathway, mediates the inhibition of autophagy through a variety of ways (See Figure 2A). Contrarily, PTEN, the phosphatase and tensin homolog, reduces the level of PIP3 and initiates the formation of autophagosome [113]. PTEN has a strong phosphatase activity for dephosphorylating PIP3 to become PIP2 which contributes to the inactivation of AKT [114]. PTEN inhibits PI3K/AKT signaling and is frequently reduced or mutated in human cancers $[115,116]$. These reveal that $\mathrm{PI} 3 \mathrm{~K} / \mathrm{AKT}$ signaling may be positively related with the proliferation and migration of HCC. Actually, a variety of studies had indicated that repression of the PI3K/AKT/ mTOR signaling pathway restricted the growth of $\mathrm{HCC}$ cells. A recent report suggested that knockdown of PI3K/ AKT/mTOR suppressed the proliferation and migration of HCC cells [118], which demonstrated that inhibition of PI3K/AKT could be an effective molecular target for HCC therapy. Furthermore, arenobufagin (a bufadienolide from toad venom) suppressed the growth of HCC cells by inducing the initiation of autophagy in human hepatocellular carcinoma cells through inhibition of PI3K/ AKT/mTOR pathway. [119]. It suggests that blocking of $\mathrm{PI} 3 \mathrm{~K} / \mathrm{AKT} / \mathrm{mTOR}$ signaling can induce the occurrence of autophagy and contribute to the suppression of HCC.

All these lines of evidence suggest that suppression of $\mathrm{PI} 3 \mathrm{~K} / \mathrm{AKT} / \mathrm{mTOR}$ signaling pathway induces the initiation of autophagy, and then inhibits the proliferation and migration of HCC cells.

\section{ERK/MAPK pathway}

ERK/MAPK pathway, also known as RAF/ $\mathrm{MEK} / \mathrm{ERK}$ pathway, is an evolutionarily conserved signaling pathway that responds to signals from cell 
surface receptors to promote cell growth, proliferation, survival, and differentiation [120]. More significantly, the frequent mutations in members of this pathway are believed to contribute to tumorigenesis, tumor progression and metastasis in many solid tumors including HCC [121-124]. A recent clinical survey showed that BRAF (mutated RAF paralogue) mutation was associated with a poor median RFS (recurrence free survival rate), higher recurrence rate and mortality after hepatic cancer resection. It suggested that BRAF mutation could be an effective prognostic marker after surgical treatment of liver cancer [125]. Furthermore, a 46 HCC cases study showed that activation of MEK1/2, overexpression of ERK1/2, and hyperphosphorylation of ERK1/2 were respectively detected in $100 \%, 91 \%$ and $69 \%$ of $\mathrm{HCC}$ patients [126]. Accordingly, abnormal expression of members of RAF/MEK/ERK pathway contributes to the development of HCC.

Moreover, ERK can trigger autophagy by inhibiting mTORC1 (See Figure 2B) [127]. Activated Ras can induce high levels of basal autophagy in human cancer cell lines during nutrient rich state and requires autophagy to maintain its effect of tumorigenesis (See Figure 2B) [103, 128]. Briefly, ERK/MAPK pathway promotes the development of tumors through various ways including the induction of autophagy. However, whether the HCC promotion role is mediated by autophagy or not is rarely reported. Inhibition of members of ERK/MAPK pathway could block the progression of HCC cells. Indeed, researchers have been devoted much energy to the research of pathway inhibitors, some of which now have been found or even been approved for treatment of tumors [102, 129].

\section{PERK pathway}

PERK (PRKR-like ER kinase) pathway is one of the signal branches of UPR (unfolded protein response). UPR is triggered by accumulation of excessive unfolded proteins when the unfolded proteins exceed the protein synthesis and folding capacity of ER (endoplasmic reticulum) [130]. It has been reported that autophagy was the downstream of the PERK signal axis and eventually led to survival of tumor cells (See Figure 2C) [131]. However, the PERK signal axis can also mediate the apoptosis of HCC cells through autophagy. The insufficient correction of misfolded proteins could induce the apoptosis of tumor cells [132]. Due to the dynamic functions of PERK induced autophagy, balance of the PERK signal in HCC cells could sensitize cancer cells to tough environment [132, 133].

\section{Wnt/ $\beta$-catenin signaling pathway}

Increasing evidences demonstrated that the $\mathrm{Wnt} / \beta$-catenin pathway played a major role in hepatic oncogenesis $[134,135]$. In the presence of Wnt ligand, the pathway is on state and $\beta$-catenin (a transcription factor as a key component of the Wnt signaling pathway) is increasing (See Figure 2D). Then $\beta$-catenin enters the nucleus and coordinately up-regulates the expression of target genes involved in cell proliferation, migration, invasion, cell cycle progression, and metastasis, which facilitate the development of HCC [135-137].

Besides, Wnt/ $\beta$-catenin signaling can negatively regulate autophagy. $\beta$-catenin acts as a transcriptional co-repressor of p62 to limit autophagy in nutrient rich condition. Interestingly, $\beta$-catenin is itself directly interacting with LC3 and hence is specifically targeted for degradation by autophagy in starvation stress (See Figure 2D). These results suggest that autophagy and Wnt/ $\beta$-catenin signaling crosstalk mechanism occupies an important role in the regulation of cell proliferation [138]. However, the relationship among autophagy, Wnt/ $\beta$ catenin pathway, and HCC has not been reported until now. Considering the abnormal expression of $\beta$-catenin in HCC and the relationship between autophagy and $\beta$-catenin [139-141], it could be a new target for HCC research to investigate the relationship among $\beta$-catenin, the dynamic role of autophagy, and the development of HCC.

\section{Other pathways}

In addition to the above pathways, there are many other signaling pathways which are both associated with autophagy and hepatocarcinoma. For example, HGF/cMET signaling suppresses autophagy via interaction with PI3K/AKT pathway while overexpression of $c-M E T$ was observed in HCC samples [142, 143]. By promotion or inhibition of autophagy, these pathways affect the development of HCC [144, 145].

\section{Potential prognostic biomarkers and therapy value of autophagy in $\mathrm{HCC}$}

\section{Prognostic biomarkers of autophagy in HCC}

$\mathrm{HCC}$ is the third leading cause of cancer death worldwide with a strong ability of invasion and metastasis [10]. Although surgical resection or transplantation helps to improve survival rates of patients, there is still a high recurrence rate and a poor long-term survival in HCC patients [146]. It is critical to predict individual recurrence risk and prognosis of HCC. Unfortunately, current biomarkers such as AFP (alphafetoprotein) cannot meet the specificity and sensitivity of prognostic prediction [147]. Therefore, more sensitive and more specific prognostic biomarkers are required for effective early diagnosis of HCC recurrence.

LC3-II, a widely used autophagic biomarker, was revealed to play a significant role for the development of cancer and associated with the poor survival of cancer patients [96, 148-150]. Wu et al. reported that LC3-II was overexpressed in tumor region when compared with 
normal adjacent tissues and the expression levels of LC3-II were positively related with vascular invasion and lymph node metastasis of HCC patients. Besides, they found abnormal expression of LC3-II predicted a lower OS for early HCC. All these lines of evidence revealed that LC3II was a potential biomarker of OS for HCC [95].

The expression level of Beclin 1 may be a valuable OS marker for HCC. A study on 103 primary HCC patients showed that the levels of Beclin 1 were significantly lower in HCC tissues than in adjacent tissues (72.8 vs. $89.5 \%$, $P=0.015)$. Meanwhile, Cox regression analysis revealed that Beclin 1 expression was an independent indicator for the OS of HCC patients $(P<0.05)$ [151]. It is not hard to understand that the expression level of Beclin 1 may be a valuable prognostic marker of liver cancer and loss or lower expression of Beclin 1 may suggest an inferior prognosis of $\mathrm{HCC}$.

However, it is difficult to understand autophagyassociated proteins LC3-II and Beclin 1 can be negatively related. This is, perhaps, because the two proteins are involved in different autophagic steps and interrelated with each other under certain conditions. Besides, the use

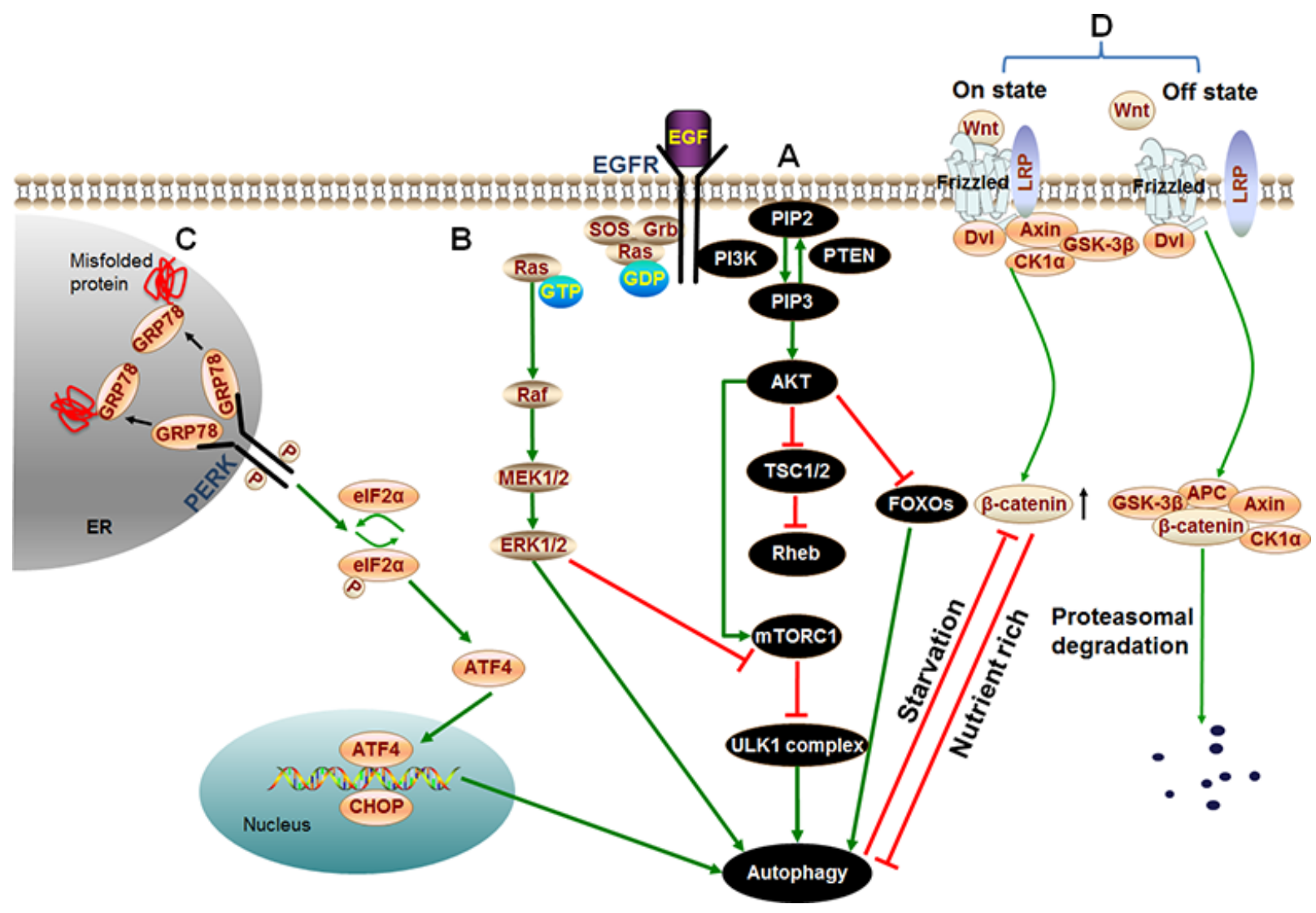

Figure 2: Signaling cascades of autophagy in HCC. (A) PI3K/AKT/mTOR pathway: Binding of growth factors to the corresponding receptors such as EGFR triggers PI3K. Then activated PI3K catalyzes the production of PIP3 which phosphorylates and activates the AKT serine/threonine kinase. Subsequently, the phosphorylated AKT activates mTORC1 resulting in repression of autophagy. Besides, activated AKT causes inactivation of TSC1/TSC2 that eventually leads to the activation of Rheb. Rheb subsequently activates mTORC1 which results in the same effect on autophagy. In addition to activating mTORC1 directly or indirectly, active AKT can also directly regulate transcription factors FOXOs resulting in inhibition of autophagy. (B) ERK/MAPK pathway: Extracellular molecules EGF, IGF or the like, bind with cell surface receptors EGFR or IGFR which then stimulate Ras. Therefore, Ras switches from inactive (GDP-bound) to the active (GTP-bound) form. Activated Ras binds to and recruits Raf kinases to the cell membrane for Raf dimerization and activation. Subsequently, activated Raf phosphorylates and activates MEK; MEK in turn phosphorylates and activates ERK/MAPK. Last, phosphorylated ERK directly activates autophagy or phosphorylates a variety of substrates in the membranes, cytoskeletal compartments, cytosol, and nucleus which can trigger autophagy by inhibiting mTORC1. (C) PERK pathway: Under conditions of accumulation of misfolded or unfolded proteins, GRP78 binds to these proteins, permitting the release of PERK, leading to activation of PERK. Activated PERK then phosphorylates eIF2 $\alpha$. PERK-eIF2 $\alpha$ activation paradoxically increases the translation of ATF4, ATF4 activates transcription factor CHOP homologous protein. Last, ATF4 and CHOP cooperatively induce autophagy. (D) Wnt/ $\beta$-catenin pathway: In the absence of Wnt signal (Off state), $\beta$-catenin is phosphorylated by APC/Axin/GSK-3 $\beta$ complex, resulting in the ubiquitination and proteasomal degradation of $\beta$-catenin. However, in the presence of Wnt ligand (On state), GSK-3 $\beta$ is displaced from the APC/Axin/GSK-3 $\beta$ complex which prevents $\beta$-catenin from being phosphorylated and subsequent proteasomal degradation. Thus, the concentration of $\beta$-catenin is increased in cytoplasm. A growing number of $\beta$-catenin limits autophagy in nutrient rich condition. While $\beta$-catenin itself is specifically targeted for degradation by autophagy in starvation stress. 
of autophagy-associated markers such as LC3-II must be complemented by assays to estimate overall autophagic flow, level of LC3-II alone cannot demonstrate the overall level of autophagy [148]. Likewise, low expression level of Beclin 1 alone does not indicate a decrease in autophagy. Autophagic flux could be assessed by following turnover of LC3-II in the absence and presence of autophagy inhibitors, and by examining the autophagy-dependent degradation of appropriate substrates, such as p62 [148]. However, as a ubiquitous cellular event, autophagy is related to various of biological and physiological process. Therefore, autophagy or autophagic biomarkers such as LC3-II would be combined with other biomarkers such as alpha-fetoprotein (AFP) or with imaging diagnosis to improve the specificity of HCC prognostic prediction.

\section{Potential therapy value of autophagy in $\mathrm{HCC}$}

The pro-tumor role of autophagy raises the possibility that autophagy inhibition may be an advantage for cancer therapy [16, 104]. Actually, efficacy of autophagy inhibitors has begun to be assessed in animal models and clinic, and the results are encouraging. Given that autophagy is an accomplice of cancer cell survival in stress conditions, autophagy inhibitors may enhance the sensitivity of cancer cells to hypoxia, metabolic stress and other tough circumstances. The tumor suppression activity of autophagy inhibitor HCQ (hydroxychloroquine), which suppresses autophagy by inhibiting the function of lysosome, has been actively assessed in mouse models [152]. The study suggested that inhibition of autophagy could enhance the death-promoting activity of tumor-suppression pathway [15]. In addition, inhibitors of autophagy such as 3-MA (3-methyladenine) which blocks the fusion between autophagosome and lysosome can enhance pro-apoptotic effects of meloxicam in $\mathrm{HCC}$ cells. Meloxicam is a selective COX-2 (cyclooxygenase 2) inhibitor which has anti-tumor effects on various tumors $[130,153]$. And multiple ATG proteins posttranslational modifications (PTMs) can block the process of autophagy which provide new therapeutic targets for the treatment of HCC $[9,43]$. Thus, inhibition of autophagy promotes the death of $\mathrm{HCC}$ cells but also has significant synergistic antitumor effects with antineoplastic agents.

Nevertheless, the physiological functions of autophagy are critical for some normal cells and tissues. A serious question is whether systemic autophagy defect will be sufficiently targeting to impair cancer growth while preventing normal tissues from the detrimental effects. We need to establish whether tumors are more susceptible to autophagy deletion than normal tissues, therefore providing a therapeutic window for patients who would most benefit from this treatment $[16,154]$.

Therefore, inhibitors of members of some autophagy-associated pathways may exert antitumor effects on HCC therapy. Indeed, inhibitors of several autophagy-associated pathways have been found to be potential targets for HCC intervention. Among the known inhibitors, sorafenib is the earliest approved molecular targeting therapeutic drug for HCC patients with liver resection or at advanced stage. It inhibits components of the RAF/MEK/ERK signaling pathway, blocks tumor growth and the pro-angiogenic factor receptors, thus inhibiting neoangiogenesis [155]. In the pivotal sorafenib phase III SHARP (Sorafenib HCC Assessment Randomized Protocol) trial, a double-blind RCT (randomized controlled trial) with a primary endpoint of OS, sorafenib significantly prolonged the OS of patients with advanced HCC from 7.9 to 10.7 months (hazard ratio $[\mathrm{HR}], 0.69 ; 95 \%$ confidence interval [CI], 0.55-0.87; $P=0.001)$. A parallel phase III RCT measured in the Asia-Pacific region, sorafenib also showed longer median OS (6.5 vs. 4.2 months) in patients with advanced HCC (HR, 0.68; 95\% CI, 0.50-0.93; $P=0.014)$. Although side effects were observed in both trials, sorafenib was the first and the only targeted therapy to demonstrate an OS benefit in patients with advanced HCC and was approved for clinical use in several countries [102, 129]. However, sorafenib can also induce autophagy which promotes cell survival in hepatocellular carcinoma either in vivo or in vitro by an ERK/MAPK pathway independent way [156]. Besides, a study confirmed this conclusion by analyzing the potential link between sorafenib and autophagy in patients [157]. Sorafenib could kill more HCC cells with improving antiproliferative ability when autophagy was repressed by chloroquine (CQ) or bafilomycin A1 or by a siRNA (small interfering RNA) against Beclin 1 or ATG5 [158]. Thus, autophagy contributes to the appearance of resistant cells and inhibition of autophagy could help to improve the efficiency of sorafenib. But some studies showed that sorafenib induced autophagy promoted programmed cellular death in HCC cells both in vitro and in vivo models [159]. The different results suggest that normalization of autophagy may be one of the key mechanisms to avoid cellular resistance to sorafenib or other antineoplastic agents $[160,161]$. In addition to sorafenib, many other signaling pathway inhibitors such as lenvatinib and tivantinib have been in clinical trial stage or have been approved in clinical use. These inhibitors block the autophagy-associated pathways including the ERK/ MAPK cascade, the PKC (protein kinase C) pathway, and the PI3K/AKT pathway [162].

Collectively, balance or inhibition of autophagy or autophagy-associated pathways could enhance the anticancer efficiency of both native tumor-suppressor mechanisms and chemotherapy to restrain tumor growth and progression.

\section{Conclusion and future directions}

In conclusion, autophagy plays an anti-tumor role in normal liver cells by maintaining cell homeostasis, 
but once the tumor is formed, it promotes the survival of HCC cells under tumor microenvironment. Several vital pathways including PI3K/AKT, RAF/MEK/MAPK, PERK, and $W n t / \beta$-catenin signaling pathways are involved in the autophagy procedure and the regulation of HCC initiation and progression. Many core molecules mentioned in these signaling pathways can be used as prognostic biomarkers or therapeutic targets for HCC. However, what we have known about autophagy in HCC so far is just the tip of the iceberg. A better understanding of the mechanisms by which autophagy exerts different functions at different stages of HCC is important and urgently needed. As autophagy is a ubiquitous cellular event, exploration on tumor-specific autophagy loss and effective pharmacological agents for blocking of autophagy in cancer cells may be a great hotspot and breakthrough point for reducing HCC risk and improving HCC therapeutic efficacy.

\section{Abbreviations}

HCC: Hepatocellular carcinoma; PI3K: Phosphatidylinositol 3-kinase; AKT: Protein kinase B; mTORC1: Mammalian target of rapamycin complex 1; ERK: Extracellular signal-regulated kinase; MAPK: Mitogen-activated protein kinase; PERK: PKR-like endoplasmic reticulum kinase; LncRNA PTENP1: Long non-coding RNA PTENP1; OS: Overall survival; ULK1: Mammalian homolog of yeast Atg1; PI3KC III: Class III phosphatidylinositol 3-kinase complex; LC3: Microtubule-associated protein light chain 3; WIPI-2: WD-repeat protein interacting with phosphoinositides 2 ; FIP200: Focal adhesion kinase family interacting protein of $200 \mathrm{kD}$; RB1CC1: Retinoblastoma 1-inducible coiledcoil 1; Vps34: Phosphatidylinositol 3-kinase; hVps15: Ser/ Thr protein kinase; ER: Endoplasmic reticulum; PTMs: Posttranslational modifications; MEFs: Murine embryonic fibroblasts; TCA: Tricarboxylic acid; BEC-1: Beclin 1 ortholog; CR: Caloric restriction; CMV: Cytomegalovirus; IGF2: Insulin-like Growth Factor II; HBV: Hepatitis B virus; HPCs: Hepatic progenitor cells; IFN- $\gamma$ : Interferon gamma; FDA: Food and Drug Administration; PIP3: Phosphatidylinositol 3,4,5-trisphosphate; MEK: MAPK kinase; RFS: Recurrence free survival rate; UPR: Unfolded protein response; HGF: Hepatocyte growth factor; AFP: Alpha-fetoprotein; HCQ: Hydroxychloroquine; 3-MA: 3-methyladenine; COX-2: Cyclooxygenase 2; SHARP: Sorafenib HCC Assessment Randomized Protocol; RCT: Randomized controlled trial; CQ: Chloroquine; siRNA: Small interfering RNA; PKC: Protein kinase C; IGFR: Insulin-like Growth Factor receptor; EGF: Epidermal growth factor; EGFR: EGF receptor; PIP2: Phosphatidylinositol-4,5-bisphosphate; GRP78: Glucose regulated protein $78 \mathrm{kDa}$; eIF2 $\alpha$ : Eukaryotic translation initiation factor $2 \alpha$; ATF4: Activating transcription factor 4; CHOP: C/EBP homologous protein; SOS: Son of sevenless; TSC1/2: Target of rapamycin complex 1/2; FOXOs: Forkhead box protein O; Rheb: Ras homolog enriched in brain; LRP: Lipoprotein receptor-related protein; Dvl: Dishevelled; GSK-3 $\beta$ : Glycogen synthase kinase 3 $\beta$; CK1 $\alpha$ : Casein kinase 1 $\alpha$; APC: Adenomatous polyposis coli; Bcl2: B cell leukemia 2.

\section{ACKNOWLEDGMENTS AND FUNDING}

This work was financially supported by the National Natural Science Foundation of China (Nos. 81372663, 81472832, 81672392).

\section{CONFLICTS OF INTEREST}

None declared.

\section{REFERENCES}

1. Klionsky DJ. Autophagy: from phenomenology to molecular understanding in less than a decade. Nat Rev Mol Cell Bio. 2007; 8:931-937.

2. Klionsky DJ. The molecular machinery of autophagy: unanswered questions. J Cell Sci. 2005; 118:7-18.

3. Yorimitsu T, Klionsky DJ. Autophagy: molecular machinery for self-eating. Cell Death Differ. 2005; 12:1542-1552.

4. Yang Z, Klionsky DJ. Mammalian autophagy: core molecular machinery and signaling regulation. Current opinion in cell biology. 2010; 22:124-131.

5. Mizushima N. Physiological Functions of Autophagy. Curr Top Microbiol. 2009; 335:71-84.

6. Koenig AB, Mehta R, Bratthauer G, Monge F, Goodman ZD, Younossi ZM. Nuclear localization of autophagy marker LC3 is associated with fibrosis in nonalcoholic fatty liver disease (NAFLD). Hepatology. 2015; 62:649a-650a.

7. Bianco A, Muller S. Nanomaterials, Autophagy, and Lupus Disease. Chemmedchem. 2016; 11:166-174.

8. Cadwell K, Liu JY, Brown SL, Miyoshi H, Loh J, Lennerz JK, Kishi C, Kc W, Carrero JA, Hunt S, Stone CD, Brunt EM, Xavier RJ, et al. A key role for autophagy and the autophagy gene Atg1611 in mouse and human intestinal Paneth cells. Nature. 2008; 456:259-U262.

9. Gozuacik D, Kimchi A. Autophagy as a cell death and tumor suppressor mechanism. Oncogene. 2004; 23:2891-2906.

10. El-Serag HB. Epidemiology of viral hepatitis and hepatocellular carcinoma. Gastroenterology. 2012; 142:1264-1273 e1261.

11. Torre LA, Bray F, Siegel RL, Ferlay J, Lortet-Tieulent J, Jemal A. Global cancer statistics, 2012. CA Cancer J Clin. 2015; 65:87-108.

12. Kim BK, Kim SU, Park JY, Kim DY, Ahn SH, Park MS, Kim EH, Seong J, Lee DY, Han KH. Applicability of 
BCLC stage for prognostic stratification in comparison with other staging systems: single centre experience from long-term clinical outcomes of 1717 treatment-naive patients with hepatocellular carcinoma. Liver Int. 2012; 32:1120-1127.

13. European Association For The Study Of The Liver, European Organisation For Research and Treatment Of Cancer. EASL-EORTC clinical practice guidelines: management of hepatocellular carcinoma. J Hepatol. 2012; 56:908-943.

14. Shintani T, Klionsky DJ. Autophagy in health and disease: A double-edged sword. Science. 2004; 306:990-995.

15. White E, DiPaola RS. The double-edged sword of autophagy modulation in cancer. Clin Cancer Res. 2009; 15:5308-5316.

16. White E. The role for autophagy in cancer. J Clin Invest. 2015; 125:42-46.

17. Matsuura A, Tsukada M, Wada Y, Ohsumi Y. Apg1p, a novel protein kinase required for the autophagic process in Saccharomyces cerevisiae. Gene. 1997; 192:245-250.

18. Feng Y, Yao Z, Klionsky DJ. How to control self-digestion: transcriptional, post-transcriptional, and post-translational regulation of autophagy. Trends Cell Biol. 2015; 25:354-363.

19. Ganley IG, Lam H, Wang J, Ding X, Chen S, Jiang X. ULK1.ATG13.FIP200 complex mediates mTOR signaling and is essential for autophagy. J Biol Chem. 2009; 284:12297-12305.

20. Hosokawa N, Hara T, Kaizuka T, Kishi C, Takamura A, Miura Y, Iemura S, Natsume T, Takehana K, Yamada N, Guan JL, Oshiro N, Mizushima N. Nutrient-dependent mTORC1 association with the ULK1-Atg13-FIP200 complex required for autophagy. Mol Biol Cell. 2009; 20:1981-1991.

21. Kim J, Kundu M, Viollet B, Guan KL. AMPK and mTOR regulate autophagy through direct phosphorylation of Ulk1. Nat Cell Biol. 2011; 13:132-141.

22. Egan DF, Shackelford DB, Mihaylova MM, Gelino S, Kohnz RA, Mair W, Vasquez DS, Joshi A, Gwinn DM, Taylor R, Asara JM, Fitzpatrick J, Dillin A, et al. Phosphorylation of ULK1 (hATG1) by AMP-activated protein kinase connects energy sensing to mitophagy. Science. 2011; 331:456-461.

23. Itakura E, Mizushima N. Characterization of autophagosome formation site by a hierarchical analysis of mammalian Atg proteins. Autophagy. 2010; 6:764-776.

24. Mercer CA, Kaliappan A, Dennis PB. A novel, human Atg13 binding protein, Atg101, interacts with ULK1 and is essential for macroautophagy. Autophagy. 2009; 5:649-662.

25. Hosokawa N, Sasaki T, Iemura S, Natsume T, Hara T, Mizushima N. Atg101, a novel mammalian autophagy protein interacting with Atg13. Autophagy. 2009; 5:973-979.

26. Parzych KR, Klionsky DJ. An overview of autophagy: morphology, mechanism, and regulation. Antioxid Redox Signal. 2014; 20:460-473.
27. Wong PM, Puente C, Ganley IG, Jiang X. The ULK1 complex: sensing nutrient signals for autophagy activation. Autophagy. 2013; 9:124-137.

28. Itakura E, Kishi C, Inoue K, Mizushima N. Beclin 1 forms two distinct phosphatidylinositol 3-kinase complexes with mammalian Atg14 and UVRAG. Mol Biol Cell. 2008; 19:5360-5372.

29. Mizushima N, Yoshimori T, Ohsumi Y. The Role of Atg Proteins in Autophagosome Formation. Annu Rev Cell Dev Biol. 2011; 27:107-132.

30. Zhong Y, Wang QJ, Li X, Yan Y, Backer JM, Chait BT, Heintz N, Yue Z. Distinct regulation of autophagic activity by $\operatorname{Atg} 14 \mathrm{~L}$ and Rubicon associated with Beclin 1-phosphatidylinositol-3-kinase complex. Nat Cell Biol. 2009; 11:468-U262.

31. Barth S, Glick D, Macleod KF. Autophagy: assays and artifacts. J Pathol. 2010; 221:117-124.

32. Weidberg H, Shvets E, Elazar Z. Biogenesis and cargo selectivity of autophagosomes. Annu Rev Biochem. 2011; 80:125-156.

33. Kirkin V, McEwan DG, Novak I, Dikic I. A role for ubiquitin in selective autophagy. Mol Cell. 2009; 34:259-269.

34. Geng J, Klionsky DJ. The Atg8 and Atg12 ubiquitinlike conjugation systems in macroautophagy. 'Protein modifications: beyond the usual suspects' review series. Embo Rep. 2008; 9:859-864.

35. Polson HE, de Lartigue J, Rigden DJ, Reedijk M, Urbe S, Clague MJ, Tooze SA. Mammalian Atg18 (WIPI2) localizes to omegasome-anchored phagophores and positively regulates LC3 lipidation. Autophagy. 2010; 6:506-522.

36. Velikkakath AK, Nishimura T, Oita E, Ishihara N, Mizushima N. Mammalian Atg2 proteins are essential for autophagosome formation and important for regulation of size and distribution of lipid droplets. Mol Biol Cell. 2012; 23:896-909.

37. Young AR, Chan EY, Hu XW, Kochl R, Crawshaw SG, High S, Hailey DW, Lippincott-Schwartz J, Tooze SA. Starvation and ULK1-dependent cycling of mammalian Atg9 between the TGN and endosomes. J Cell Sci. 2006; 119:3888-3900.

38. Yla-Anttila P, Vihinen H, Jokitalo E, Eskelinen EL. 3D tomography reveals connections between the phagophore and endoplasmic reticulum. Autophagy. 2009; 5:1180-1185.

39. Xie Z, Klionsky DJ. Autophagosome formation: Core machinery and adaptations. Nat Cell Biol. 2007; 9:1102-1109.

40. Glick D, Barth S, Macleod KF. Autophagy: cellular and molecular mechanisms. J Pathol. 2010; 221:3-12.

41. Boya P, Reggiori F, Codogno P. Emerging regulation and functions of autophagy. Nat Cell Biol. 2013; 15:713-720.

42. Subramani S, Malhotra V. Non-autophagic roles of autophagy-related proteins. Embo Rep. 2013; 14:143-151.

43. Xie Y, Kang R, Sun X, Zhong M, Huang J, Klionsky DJ, Tang D. Posttranslational modification of autophagy-related proteins in macroautophagy. Autophagy. 2015; 11:28-45. 
44. Bach M, Larance M, James DE, Ramm G. The serine/threonine kinase ULK1 is a target of multiple phosphorylation events. Biochem J. 2011; 440:283-291.

45. Nazio F, Strappazzon F, Antonioli M, Bielli P, Cianfanelli V, Bordi M, Gretzmeier C, Dengjel J, Piacentini M, Fimia GM, Cecconi F. mTOR inhibits autophagy by controlling ULK1 ubiquitylation, self-association and function through AMBRA1 and TRAF6. Nat Cell Biol. 2013; 15:406-416.

46. Lin SY, Li TY, Liu Q, Zhang C, Li X, Chen Y, Zhang SM, Lian G, Liu Q, Ruan K, Wang Z, Zhang CS, Chien KY, et al. GSK3-TIP60-ULK1 signaling pathway links growth factor deprivation to autophagy. Science. 2012; 336:477-481.

47. Lockwood TD, Minassian IA. Protein turnover and proliferation. Failure of SV-3T3 cells to increase lysosomal proteinases, increase protein degradation and cease net protein accumulation. Biochem J. 1982; 206:251-258.

48. Schwarze PE, Seglen PO. Reduced autophagic activity, improved protein balance and enhanced in vitro survival of hepatocytes isolated from carcinogen-treated rats. Exp Cell Res. 1985; 157:15-28.

49. Canuto RA, Tessitore L, Muzio G, Autelli R, Baccino FM. Tissue protein turnover during liver carcinogenesis. Carcinogenesis. 1993; 14:2581-2587.

50. Kisen GO, Tessitore L, Costelli P, Gordon PB, Schwarze PE, Baccino FM, Seglen PO. Reduced autophagic activity in primary rat hepatocellular carcinoma and ascites hepatoma cells. Carcinogenesis. 1993; 14:2501-2505.

51. Kihara A, Kabeya Y, Ohsumi Y, Yoshimori T. Beclinphosphatidylinositol 3-kinase complex functions at the trans-Golgi network. Embo Rep. 2001; 2:330-335.

52. Liang XH, Jackson S, Seaman M, Brown K, Kempkes B, Hibshoosh H, Levine B. Induction of autophagy and inhibition of tumorigenesis by beclin 1. Nature. 1999; 402:672-676.

53. Saito H, Inazawa J, Saito S, Kasumi F, Koi S, Sagae S, Kudo R, Saito J, Noda K, Nakamura Y. Detailed deletion mapping of chromosome $17 \mathrm{q}$ in ovarian and breast cancers: 2-cM region on 17q21.3 often and commonly deleted in tumors. Cancer Res. 1993; 53:3382-3385.

54. Gao X, Zacharek A, Salkowski A, Grignon DJ, Sakr W, Porter AT, Honn KV. Loss of heterozygosity of the BRCA1 and other loci on chromosome $17 \mathrm{q}$ in human prostate cancer. Cancer Res. 1995; 55:1002-1005.

55. Pirtoli L, Cevenini G, Tini P, Vannini M, Oliveri G, Marsili S, Mourmouras V, Rubino G, Miracco C. The prognostic role of Beclin 1 protein expression in high-grade gliomas. Autophagy. 2009; 5:930-936.

56. Li BX, Li CY, Peng RQ, Wu XJ, Wang HY, Wan DS, Zhu XF, Zhang XS. The expression of beclin 1 is associated with favorable prognosis in stage IIIB colon cancers. Autophagy. 2009; 5:303-306.

57. Miracco C, Cosci E, Oliveri G, Luzi P, Pacenti L, Monciatti I, Mannucci S, De Nisi MC, Toscano M, Malagnino V, Falzarano SM, Pirtoli L, Tosi P. Protein and
mRNA expression of autophagy gene Beclin 1 in human brain tumours. Int J Oncol. 2007; 30:429-436.

58. Arico S, Petiot A, Bauvy C, Dubbelhuis PF, Meijer AJ, Codogno P, Ogier-Denis E. The tumor suppressor PTEN positively regulates macroautophagy by inhibiting the phosphatidylinositol 3-kinase/protein kinase B pathway. J Biol Chem. 2001; 276:35243-35246.

59. Inoki $\mathrm{K}, \mathrm{Li} \mathrm{Y}, \mathrm{Zhu} \mathrm{T}$, Wu J, Guan KL. TSC2 is phosphorylated and inhibited by Akt and suppresses mTOR signalling. Nat Cell Biol. 2002; 4:648-657.

60. Tee AR, Fingar DC, Manning BD, Kwiatkowski DJ, Cantley LC, Blenis J. Tuberous sclerosis complex-1 and -2 gene products function together to inhibit mammalian target of rapamycin (mTOR)-mediated downstream signaling. Proc Natl Acad Sci USA. 2002; 99:13571-13576.

61. Chi S, Kitanaka C, Noguchi K, Mochizuki T, Nagashima Y, Shirouzu M, Fujita H, Yoshida M, Chen W, Asai A, Himeno M, Yokoyama S, Kuchino Y. Oncogenic Ras triggers cell suicide through the activation of a caspaseindependent cell death program in human cancer cells. Oncogene. 1999; 18:2281-2290.

62. Kitanaka C, Kato K, Ijiri R, Sakurada K, Tomiyama A, Noguchi K, Nagashima Y, Nakagawara A, Momoi T, Toyoda Y, Kigasawa H, Nishi T, Shirouzu M, et al. Increased Ras expression and caspase-independent neuroblastoma cell death: possible mechanism of spontaneous neuroblastoma regression. J Natl Cancer Inst. 2002; 94:358-368.

63. Tsuneoka M, Umata T, Kimura H, Koda Y, Nakajima M, Kosai K, Takahashi T, Takahashi Y, Yamamoto A. c-myc induces autophagy in rat 3 Y1 fibroblast cells. Cell Struct Funct. 2003; 28:195-204.

64. Scarlatti F, Granata R, Meijer AJ, Codogno P. Does autophagy have a license to kill mammalian cells? Cell Death Differ. 2009; 16:12-20.

65. Yu L, Alva A, Su H, Dutt P, Freundt E, Welsh S, Baehrecke EH, Lenardo MJ. Regulation of an ATG7-beclin 1 program of autophagic cell death by caspase-8. Science. 2004; 304:1500-1502.

66. Shimizu S, Kanaseki T, Mizushima N, Mizuta T, ArakawaKobayashi S, Thompson CB, Tsujimoto Y. Role of Bcl-2 family proteins in a non-apoptotic programmed cell death dependent on autophagy genes. Nat Cell Biol. 2004; 6:1221-1228.

67. Hara T, Nakamura K, Matsui M, Yamamoto A, Nakahara Y, Suzuki-Migishima R, Yokoyama M, Mishima K, Saito I, Okano H, Mizushima N. Suppression of basal autophagy in neural cells causes neurodegenerative disease in mice. Nature. 2006; 441:885-889.

68. Komatsu M, Waguri S, Ueno T, Iwata J, Murata S, Tanida I, Ezaki J, Mizushima N, Ohsumi Y, Uchiyama Y, Kominami E, Tanaka K, Chiba T. Impairment of starvationinduced and constitutive autophagy in Atg7-deficient mice. J Cell Biol. 2005; 169:425-434.

69. Komatsu M, Waguri S, Chiba T, Murata S, Iwata J, Tanida I, Ueno T, Koike M, Uchiyama Y, Kominami E, Tanaka K. 
Loss of autophagy in the central nervous system causes neurodegeneration in mice. Nature. 2006; 441:880-884.

70. Nakai A, Yamaguchi O, Takeda T, Higuchi Y, Hikoso S, Taniike M, Omiya S, Mizote I, Matsumura Y, Asahi M, Nishida K, Hori M, Mizushima N, Otsu K. The role of autophagy in cardiomyocytes in the basal state and in response to hemodynamic stress. Nat Med. 2007; 13:619-624.

71. Onodera J, Ohsumi Y. Autophagy is required for maintenance of amino acid levels and protein synthesis under nitrogen starvation. J Biol Chem. 2005; 280:31582-31586

72. Rubinsztein DC, Marino G, Kroemer G. Autophagy and aging. Cell. 2011; 146:682-695.

73. Madeo F, Zimmermann A, Maiuri MC, Kroemer G. Essential role for autophagy in life span extension. J Clin Invest. 2015; 125:85-93.

74. Lipinski MM, Zheng B, Lu T, Yan Z, Py BF, Ng A, Xavier RJ, Li C, Yankner BA, Scherzer CR, Yuan J. Genome-wide analysis reveals mechanisms modulating autophagy in normal brain aging and in Alzheimer's disease. Proc Natl Acad Sci USA. 2010; 107:14164-14169.

75. Melendez A, Talloczy Z, Seaman M, Eskelinen EL, Hall DH, Levine B. Autophagy genes are essential for dauer development and life-span extension in C. elegans. Science. 2003; 301:1387-1391.

76. Levine B, Kroemer G. Autophagy in the pathogenesis of disease. Cell. 2008; 132:27-42.

77. Colman RJ, Anderson RM, Johnson SC, Kastman EK, Kosmatka KJ, Beasley TM, Allison DB, Cruzen C, Simmons HA, Kemnitz JW, Weindruch R. Caloric restriction delays disease onset and mortality in rhesus monkeys. Science. 2009; 325:201-204.

78. Jia K, Levine B. Autophagy is required for dietary restriction-mediated life span extension in C. elegans. Autophagy. 2007; 3:597-599.

79. Demontis F, Perrimon N. FOXO/4E-BP signaling in Drosophila muscles regulates organism-wide proteostasis during aging. Cell. 2010; 143:813-825.

80. Eisenberg $\mathrm{T}$, Knauer $\mathrm{H}$, Schauer A, Buttner $\mathrm{S}$, Ruckenstuhl C, Carmona-Gutierrez D, Ring J, Schroeder S, Magnes C, Antonacci L, Fussi H, Deszcz L, Hartl R, et al. Induction of autophagy by spermidine promotes longevity. Nat Cell Biol. 2009; 11:1305-1314.

81. Harrison DE, Strong R, Sharp ZD, Nelson JF, Astle CM, Flurkey K, Nadon NL, Wilkinson JE, Frenkel K, Carter CS, Pahor M, Javors MA, Fernandez E, et al. Rapamycin fed late in life extends lifespan in genetically heterogeneous mice. Nature. 2009; 460:392-395.

82. Chang Y, Lin J, Tsung A. Manipulation of autophagy by MIR375 generates antitumor effects in liver cancer. Autophagy. 2012; 8:1833-1834.

83. Sun K, Guo XL, Zhao QD, Jing YY, Kou XR, Xie XQ, Zhou Y, Cai N, Gao L, Zhao X, Zhang SS, Song JR, Li D, et al. Paradoxical role of autophagy in the dysplastic and tumor-forming stages of hepatocarcinoma development in rats. Cell Death Dis. 2013; 4:e501.

84. Yue Z, Jin S, Yang C, Levine AJ, Heintz N. Beclin 1, an autophagy gene essential for early embryonic development, is a haploinsufficient tumor suppressor. Proc Natl Acad Sci USA. 2003; 100:15077-15082.

85. Qu X, Yu J, Bhagat G, Furuya N, Hibshoosh H, Troxel A, Rosen J, Eskelinen EL, Mizushima N, Ohsumi Y, Cattoretti G, Levine B. Promotion of tumorigenesis by heterozygous disruption of the beclin 1 autophagy gene. J Clin Invest. 2003; 112:1809-1820.

86. Cianfanelli V, Fuoco C, Lorente M, Salazar M, Quondamatteo F, Gherardini PF, De Zio D, Nazio F, Antonioli M, D’Orazio M, Skobo T, Bordi M, Rohde M, et al. AMBRA1 links autophagy to cell proliferation and tumorigenesis by promoting c-Myc dephosphorylation and degradation. Nat Cell Biol. 2015; 17:706.

87. Takamura A, Komatsu M, Hara T, Sakamoto A, Kishi C, Waguri S, Eishi Y, Hino O, Tanaka K, Mizushima N. Autophagy-deficient mice develop multiple liver tumors. Genes Dev. 2011; 25:795-800.

88. Kessler SM, Laggai S, Barghash A, Schultheiss CS, Lederer E, Artl M, Helms V, Haybaeck J, Kiemer AK. IMP2/p62 induces genomic instability and an aggressive hepatocellular carcinoma phenotype. Cell Death Dis. 2015; 6:e1894.

89. Xue F, Hu L, Ge R, Yang L, Liu K, Li Y, Sun Y, Wang K. Autophagy-deficiency in hepatic progenitor cells leads to the defects of stemness and enhances susceptibility to neoplastic transformation. Cancer Lett. 2016; 371:38-47.

90. White E. Deconvoluting the context-dependent role for autophagy in cancer. Nat Rev Cancer. 2012; 12:401-410.

91. Hollander MC, Blumenthal GM, Dennis PA. PTEN loss in the continuum of common cancers, rare syndromes and mouse models. Nat Rev Cancer. 2011; 11:289-301.

92. Chen $\mathrm{CL}$, Tseng YW, Wu JC, Chen GY, Lin KC, Hwang SM, Hu YC. Suppression of hepatocellular carcinoma by baculovirus-mediated expression of long non-coding RNA PTENP1 and MicroRNA regulation. Biomaterials. 2015; 44:71-81.

93. Tay Y, Kats L, Salmena L, Weiss D, Tan SM, Ala U, Karreth F, Poliseno L, Provero P, Di Cunto F, Lieberman J, Rigoutsos I, Pandolfi PP. Coding-independent regulation of the tumor suppressor PTEN by competing endogenous mRNAs. Cell. 2011; 147:344-357.

94. Li P, Du Q, Cao Z, Guo Z, Evankovich J, Yan W, Chang Y, Shao L, Stolz DB, Tsung A, Geller DA. Interferon-gamma induces autophagy with growth inhibition and cell death in human hepatocellular carcinoma (HCC) cells through interferon-regulatory factor-1 (IRF-1). Cancer Lett. 2012; 314:213-222.

95. Wu DH, Jia CC, Chen J, Lin ZX, Ruan DY, Li X, Lin Q, Min D, Ma XK, Wan XB, Cheng N, Chen ZH, Xing YF, et al. Autophagic LC3B overexpression correlates with malignant 
progression and predicts a poor prognosis in hepatocellular carcinoma. Tumour Biol. 2014; 35:12225-12233.

96. Lazova R, Camp RL, Klump V, Siddiqui SF, Amaravadi RK, Pawelek JM. Punctate LC3B expression is a common feature of solid tumors and associated with proliferation, metastasis, and poor outcome. Clin Cancer Res. 2012; 18:370-379.

97. Mikhaylova O, Stratton Y, Hall D, Kellner E, Ehmer B, Drew AF, Gallo CA, Plas DR, Biesiada J, Meller J, CzyzykKrzeska MF. VHL-regulated MiR-204 suppresses tumor growth through inhibition of LC3B-mediated autophagy in renal clear cell carcinoma. Cancer cell. 2012; 21:532-546.

98. He XX, Chang Y, Meng FY, Wang MY, Xie QH, Tang F, Li PY, Song YH, Lin JS. MicroRNA-375 targets AEG-1 in hepatocellular carcinoma and suppresses liver cancer cell growth in vitro and in vivo. Oncogene. 2012; 31:3357-3369.

99. Chang Y, Yan W, He X, Zhang L, Li C, Huang H, Nace G, Geller DA, Lin J, Tsung A. miR-375 Inhibits Autophagy and Reduces Viability of Hepatocellular Carcinoma Cells Under Hypoxic Conditions. Gastroenterology. 2012; 143:177-187 e178.

100. Tian Y, Kuo CF, Sir D, Wang L, Govindarajan S, Petrovic LM, $\mathrm{Ou}$ JH. Autophagy inhibits oxidative stress and tumor suppressors to exert its dual effect on hepatocarcinogenesis. Cell Death Differ. 2015; 22:1025-1034.

101. Yuan H, Li AJ, Ma SL, Cui LJ, Wu B, Yin L, Wu MC. Inhibition of autophagy significantly enhances combination therapy with sorafenib and HDAC inhibitors for human hepatoma cells. World J Gastroenterol. 2014; 20:4953-4962.

102. Llovet JM, Ricci S, Mazzaferro V, Hilgard P, Gane E, Blanc JF, de Oliveira AC, Santoro A, Raoul JL, Forner A, Schwartz M, Porta C, Zeuzem S, et al. Sorafenib in advanced hepatocellular carcinoma. N Engl J Med. 2008; 359:378-390.

103. Guo JY, Chen HY, Mathew R, Fan J, Strohecker AM, KarsliUzunbas G, Kamphorst JJ, Chen G, Lemons JM, Karantza V, Coller HA, Dipaola RS, Gelinas C, et al. Activated Ras requires autophagy to maintain oxidative metabolism and tumorigenesis. Genes Dev. 2011; 25:460-470.

104. Guo JY, Xia B, White E. Autophagy-mediated tumor promotion. Cell. 2013; 155:1216-1219.

105. Song J, Qu Z, Guo X, Zhao Q, Zhao X, Gao L, Sun K, Shen F, Wu M, Wei L. Hypoxia-induced autophagy contributes to the chemoresistance of hepatocellular carcinoma cells. Autophagy. 2009; 5:1131-1144.

106. Yeh YC, Tsai JF, Chuang LY, Yeh HW, Tsai JH, Florine DL, Tam JP. Elevation of transforming growth factor alpha and its relationship to the epidermal growth factor and alphafetoprotein levels in patients with hepatocellular carcinoma. Cancer Res. 1987; 47:896-901.

107. Harada K, Shiota G, Kawasaki H. Transforming growth factor-alpha and epidermal growth factor receptor in chronic liver disease and hepatocellular carcinoma. Liver. 1999; 19:318-325.
108. Ito Y, Takeda T, Higashiyama S, Sakon M, Wakasa KI, Tsujimoto M, Monden M, Matsuura N. Expression of heparin binding epidermal growth factor-like growth factor in hepatocellular carcinoma: an immunohistochemical study. Oncol Rep. 2001; 8:903-907.

109. Yoneda N, Sato Y, Kitao A, Ikeda H, Sawada-Kitamura S, Miyakoshi M, Harada K, Sasaki M, Matsui O, Nakanuma Y. Epidermal growth factor induces cytokeratin 19 expression accompanied by increased growth abilities in human hepatocellular carcinoma. Lab Invest. 2011; 91:262-272.

110. Chen YL, Law PY, Loh HH. Inhibition of PI3K/Akt signaling: an emerging paradigm for targeted cancer therapy. Curr Med Chem Anticancer Agents. 2005; 5: 575-589.

111. Song G, Ouyang G, Bao S. The activation of Akt/PKB signaling pathway and cell survival. J Cell Mol Med. 2005; 9:59-71.

112. Zhou Q, Lui VW, Yeo W. Targeting the PI3K/Akt/mTOR pathway in hepatocellular carcinoma. Future Oncol. 2011; 7:1149-1167.

113. Psyrri A, Arkadopoulos N, Vassilakopoulou M, Smyrniotis V, Dimitriadis G. Pathways and targets in hepatocellular carcinoma. Expert Rev Anticancer Ther. 2012; 12:1347-1357.

114. Maehama T, Dixon JE. The tumor suppressor, PTEN/ MMAC1, dephosphorylates the lipid second messenger, phosphatidylinositol 3,4,5-trisphosphate. J Biol Chem. 1998; 273:13375-13378.

115. Carnero A, Paramio JM. The PTEN/PI3K/AKT Pathway in vivo, Cancer Mouse Models. Front Oncol. 2014; 4:252.

116. Eng C. PTEN: one gene, many syndromes. Hum Mutat. 2003; 22:183-198.

117. He S, Lin J, Yu S, Sun S. Upregulation of PREX2 promotes the proliferation and migration of hepatocellular carcinoma cells via PTEN-AKT signaling. Oncol Lett. 2016; 11: 2223-2228.

118. Tang H, Li RP, Liang P, Zhou YL, Wang GW. miR-125a inhibits the migration and invasion of liver cancer cells via suppression of the PI3K/AKT/mTOR signaling pathway. Oncol Lett. 2015; 10:681-686.

119. Zhang DM, Liu JS, Deng LJ, Chen MF, Yiu A, Cao HH, Tian HY, Fung KP, Kurihara H, Pan JX, Ye WC. Arenobufagin, a natural bufadienolide from toad venom, induces apoptosis and autophagy in human hepatocellular carcinoma cells through inhibition of $\mathrm{PI} 3 \mathrm{~K} / \mathrm{Akt} / \mathrm{mTOR}$ pathway. Carcinogenesis. 2013; 34:1331-1342.

120. Yoon S, Seger R. The extracellular signal-regulated kinase: multiple substrates regulate diverse cellular functions. Growth factors. 2006; 24:21-44.

121. Han Y, Wu Z, Wu T, Huang Y, Cheng Z, Li X, Sun T, Xie X, Zhou Y, Du Z. Tumor-suppressive function of long noncoding RNA MALAT1 in glioma cells by downregulation of MMP2 and inactivation of ERK/MAPK signaling. Cell Death Dis. 2016; 7:e2123. 
122. Samatar AA, Poulikakos PI. Targeting RAS-ERK signalling in cancer: promises and challenges. Nat Rev Drug Discov. 2014; 13:928-942.

123. Wu XS, Wang XA, Wu WG, Hu YP, Li ML, Ding Q, Weng H, Shu YJ, Liu TY, Jiang L, Cao Y, Bao RF, Mu JS, et al. MALAT1 promotes the proliferation and metastasis of gallbladder cancer cells by activating the ERK/MAPK pathway. Cancer Biol Ther. 2014; 15:806-814.

124. Peng H, Li TW, Yang H, Moyer MP, Mato JM, Lu SC. Methionine adenosyltransferase 2B-GIT1 complex serves as a scaffold to regulate Ras/Raf/MEK1/2 activity in human liver and colon cancer cells. Am J Pathol. 2015; 185:1135-1144.

125. Schirripa M, Bergamo F, Cremolini C, Casagrande M, Lonardi S, Aprile G, Yang D, Marmorino F, Pasquini G, Sensi E, Lupi C, De Maglio G, Borrelli N, et al. BRAF and RAS mutations as prognostic factors in metastatic colorectal cancer patients undergoing liver resection. Br J Cancer. 2015; 112:1921-1928.

126. Huynh H, Nguyen TT, Chow KH, Tan PH, Soo KC, Tran E. Over-expression of the mitogen-activated protein kinase (MAPK) kinase (MEK)-MAPK in hepatocellular carcinoma: its role in tumor progression and apoptosis. BMC Gastroenterol. 2003; 3:19.

127. Maddodi N, Huang W, Havighurst T, Kim K, Longley BJ, Setaluri V. Induction of autophagy and inhibition of melanoma growth in vitro and in vivo by hyperactivation of oncogenic BRAF. J Invest Dermatol. 2010; 130:1657-1667.

128. Elgendy M, Sheridan C, Brumatti G, Martin SJ. Oncogenic Ras-induced expression of Noxa and Beclin-1 promotes autophagic cell death and limits clonogenic survival. Mol Cell. 2011; 42:23-35.

129. Cheng AL, Kang YK, Chen Z, Tsao CJ, Qin S, Kim JS, Luo R, Feng J, Ye S, Yang TS, Xu J, Sun Y, Liang H, et al. Efficacy and safety of sorafenib in patients in the AsiaPacific region with advanced hepatocellular carcinoma: a phase III randomised, double-blind, placebo-controlled trial. Lancet Oncol. 2009; 10:25-34.

130. Zhong J, Dong X, Xiu P, Wang F, Liu J, Wei H, Xu Z, Liu F, Li T, Li J. Blocking autophagy enhances meloxicam lethality to hepatocellular carcinoma by promotion of endoplasmic reticulum stress. Cell Prolif. 2015; 48:691-704.

131. B'chir W, Maurin AC, Carraro V, Averous J, Jousse C, Muranishi Y, Parry L, Stepien G, Fafournoux P, Bruhat A. The eIF2 alpha/ATF4 pathway is essential for stressinduced autophagy gene expression. Nucleic Acids Res. 2013; 41:7683-7699.

132. Wang M, Kaufman RJ. The impact of the endoplasmic reticulum protein-folding environment on cancer development. Nat Rev Cancer. 2014; 14:581-597.

133. Rzymski T, Milani M, Singleton DC, Harris AL. Role of ATF4 in regulation of autophagy and resistance to drugs and hypoxia. Cell Cycle. 2009; 8:3838-3847.

134. Whittaker S, Marais R, Zhu AX. The role of signaling pathways in the development and treatment of hepatocellular carcinoma. Oncogene. 2010; 29:4989-5005.
135. Wands JR, Kim M. WNT/beta-catenin signaling and hepatocellular carcinoma. Hepatology. 2014; 60:452-454.

136. Kimelman $\mathrm{D}, \mathrm{Xu}$ W. beta-catenin destruction complex: insights and questions from a structural perspective. Oncogene. 2006; 25:7482-7491.

137. Angers S, Moon RT. Proximal events in Wnt signal transduction. Nat Rev Mol Cell Biol. 2009; 10:468-477.

138. Petherick KJ, Williams AC, Lane JD, Ordonez-Moran P, Huelsken J, Collard TJ, Smartt HJ, Batson J, Malik K, Paraskeva C, Greenhough A. Autolysosomal beta-catenin degradation regulates Wnt-autophagy-p62 crosstalk. Embo J. 2013; 32:1903-1916.

139. Bengochea A, de Souza MM, Lefrancois L, Le Roux E, Galy O, Chemin I, Kim M, Wands JR, Trepo C, Hainaut P, Scoazec JY, Vitvitski L, Merle P. Common dysregulation of Wnt/Frizzled receptor elements in human hepatocellular carcinoma. Br J Cancer. 2008; 99:143-150.

140. White BD, Chien AJ, Dawson DW. Dysregulation of $\mathrm{Wnt} /$ beta-catenin signaling in gastrointestinal cancers. Gastroenterology. 2012; 142:219-232.

141. Khramtsov AI, Khramtsova GF, Tretiakova M, Huo D, Olopade OI, Goss KH. Wnt/beta-catenin pathway activation is enriched in basal-like breast cancers and predicts poor outcome. Am J Pathol. 2010; 176:2911-2920.

142. Liu Y, Yang Y, Ye YC, Shi QF, Chai K, Tashiro S, Onodera S, Ikejima T. Activation of ERK-p53 and ERK-mediated phosphorylation of Bcl-2 are involved in autophagic cell death induced by the c-Met inhibitor SU11274 in human lung cancer A549 cells. J Pharmacol Sci. 2012; 118:423-432.

143. Tavian D, De Petro G, Benetti A, Portolani N, Giulini SM, Barlati S. u-PA and c-MET mRNA expression is coordinately enhanced while hepatocyte growth factor mRNA is down-regulated in human hepatocellular carcinoma. Int J Cancer. 2000; 87:644-649.

144. Liebmann C. EGF receptor activation by GPCRs: an universal pathway reveals different versions. Mol Cell Endocrinol. 2011; 331:222-231.

145. Berasain C, Ujue Latasa M, Urtasun R, Goni S, Elizalde M, Garcia-Irigoyen O, Azcona M, Prieto J, Avila MA. Epidermal Growth Factor Receptor (EGFR) Crosstalks in Liver Cancer. Cancers. 2011; 3:2444-2461.

146. Chen XP, Qiu FZ, Wu ZD, Zhang ZW, Huang ZY, Chen YF. Long-term outcome of resection of large hepatocellular carcinoma. Brit J Surg. 2006; 93:600-606.

147. Zhao YJ, Ju Q, Li GC. Tumor markers for hepatocellular carcinoma. Mol Clin Oncol. 2013; 1:593-598.

148. Klionsky DJ, Abdelmohsen K, Abe A, Abedin MJ, Abeliovich $\mathrm{H}$, Acevedo Arozena A, Adachi H, Adams CM, Adams PD, Adeli K, Adhihetty PJ, Adler SG, Agam G, et al. Guidelines for the use and interpretation of assays for monitoring autophagy (3rd edition). Autophagy. 2016; 12:1-222.

149. Ko YH, Cho YS, Won HS, Jeon EK, An HJ, Hong SU, Park JH, Lee MA. Prognostic significance of autophagy- 
related protein expression in resected pancreatic ductal adenocarcinoma. Pancreas. 2013; 42:829-835.

150. Giatromanolaki A, Sivridis E, Mendrinos S, Koutsopoulos AV, Koukourakis MI. Autophagy proteins in prostate cancer: relation with anaerobic metabolism and Gleason score. Urol Oncol. 2014; 32:39 e11-38.

151. Qiu DM, Wang GL, Chen L, Xu YY, He S, Cao XL, Qin J, Zhou JM, Zhang YX, E Q. The expression of beclin-1, an autophagic gene, in hepatocellular carcinoma associated with clinical pathological and prognostic significance. BMC cancer. 2014; 14:327.

152. Maclean KH, Dorsey FC, Cleveland JL, Kastan MB. Targeting lysosomal degradation induces p53-dependent cell death and prevents cancer in mouse models of lymphomagenesis. J Clin Invest. 2008; 118:79-88.

153. Gallouet AS, Travert M, Bresson-Bepoldin L, Guilloton F, Pangault C, Caulet-Maugendre S, Lamy T, Tarte K, Guillaudeux T. COX-2-independent effects of celecoxib sensitize lymphoma B cells to TRAIL-mediated apoptosis. Clin Cancer Res. 2014; 20:2663-2673.

154. Karsli-Uzunbas G, Guo JY, Price S, Teng X, Laddha SV, Khor S, Kalaany NY, Jacks T, Chan CS, Rabinowitz JD, White E. Autophagy is required for glucose homeostasis and lung tumor maintenance. Cancer Discov. 2014; 4:914-927.

155. Wilhelm SM, Carter C, Tang L, Wilkie D, McNabola A, Rong H, Chen C, Zhang X, Vincent P, McHugh M, Cao Y, Shujath J, Gawlak S, et al. BAY 43-9006 exhibits broad spectrum oral antitumor activity and targets the RAF/MEK/ ERK pathway and receptor tyrosine kinases involved in tumor progression and angiogenesis. Cancer Res. 2004; 64:7099-7109.

156. Shimizu S, Takehara T, Hikita H, Kodama T, Tsunematsu H, Miyagi $T$, Hosui A, Ishida $H$, Tatsumi $T$, Kanto $T$, Hiramatsu N, Fujita N, Yoshimori T, Hayashi N. Inhibition of autophagy potentiates the antitumor effect of the multikinase inhibitor sorafenib in hepatocellular carcinoma. Int J Cancer. 2012; 131:548-557.

157. Guidetti A, Carlo-Stella C, Locatelli SL, Malorni W, Pierdominici M, Barbati C, Mortarini R, Devizzi L, Matteucci P, Marchiano A, Lanocita R, Farina L, Dodero A, et al. Phase II study of sorafenib in patients with relapsed or refractory lymphoma. Br J Haematol. 2012; 158:108-119.

158. Yuan H, Li AJ, Ma SL, Cui LJ, Wu B, Yin L, Wu MC. Inhibition of autophagy significantly enhances combination therapy with sorafenib and HDAC inhibitors for human hepatoma cells. World J Gastroenterol. 2014; 20:4953-4962.

159. Tai WT, Shiau CW, Chen HL, Liu CY, Lin CS, Cheng AL, Chen PJ, Chen KF. Mcl-1-dependent activation of Beclin 1 mediates autophagic cell death induced by sorafenib and SC-59 in hepatocellular carcinoma cells. Cell Death Dis. 2013; 4:e485.

160. Liu J, Fan L, Wang H, Sun G. Autophagy, a double-edged sword in anti-angiogenesis therapy. Med Oncol. 2016; 33:10.
161. Zhai B, Hu F, Jiang X, Xu J, Zhao D, Liu B, Pan S, Dong X, Tan G, Wei Z, Qiao H, Jiang H, Sun X. Inhibition of Akt reverses the acquired resistance to sorafenib by switching protective autophagy to autophagic cell death in hepatocellular carcinoma. Mol Cancer Ther. 2014; 13:1589-1598.

162. Chuma M, Terashita K, Sakamoto N. New molecularly targeted therapies against advanced hepatocellular carcinoma: From molecular pathogenesis to clinical trials and future directions. Hepatol Res. 2015; 45:E1-E11.

163. Chan EY, Longatti A, McKnight NC, Tooze SA. Kinaseinactivated ULK proteins inhibit autophagy via their conserved C-terminal domains using an Atg13-independent mechanism. Mol Cell Biol. 2009; 29:157-171.

164. Papinski D, Kraft C. Regulation of Autophagy By Signaling Through the Atg1/ULK1 Complex. J Mol Biol. 2016; 428:1725-1741.

165. Hara T, Takamura A, Kishi C, Iemura S, Natsume T, Guan JL, Mizushima N. FIP200, a ULK-interacting protein, is required for autophagosome formation in mammalian cells. J Cell Biol. 2008; 181:497-510.

166. Sun Q, Fan W, Chen K, Ding X, Chen S, Zhong Q. Identification of Barkor as a mammalian autophagy-specific factor for Beclin 1 and class III phosphatidylinositol 3-kinase. P Natl Acad Sci USA. 2008; 105:19211-19216.

167. Kim J, Kim YC, Fang C, Russell RC, Kim JH, Fan W, Liu R, Zhong Q, Guan KL. Differential regulation of distinct Vps34 complexes by AMPK in nutrient stress and autophagy. Cell. 2013; 152:290-303.

168. Jaber N, Dou Z, Chen JS, Catanzaro J, Jiang YP, Ballou LM, Selinger E, Ouyang X, Lin RZ, Zhang J, Zong WX. Class III PI3K Vps34 plays an essential role in autophagy and in heart and liver function. P Natl Acad Sci USA. 2012; 109:2003-2008.

169. Mizushima N, Noda T, Yoshimori T, Tanaka Y, Ishii T, George MD, Klionsky DJ, Ohsumi M, Ohsumi Y. A protein conjugation system essential for autophagy. Nature. 1998; 395:395-398.

170. Mizushima N, Kuma A, Kobayashi Y, Yamamoto A, Matsubae M, Takao T, Natsume T, Ohsumi Y, Yoshimori T. Mouse Apg16L, a novel WD-repeat protein, targets to the autophagic isolation membrane with the Apg12-Apg5 conjugate. J Cell Sci. 2003; 116:1679-1688.

171. Tanida I, Minematsu-Ikeguchi N, Ueno T, Kominami E. Lysosomal turnover, but not a cellular level, of endogenous LC3 is a marker for autophagy. Autophagy. 2005; 1:84-91.

172. Proikas-Cezanne T, Waddell S, Gaugel A, Frickey T, Lupas A, Nordheim A. WIPI-1alpha (WIPI49), a member of the novel 7-bladed WIPI protein family, is aberrantly expressed in human cancer and is linked to starvationinduced autophagy. Oncogene. 2004; 23:9314-9325. 